\title{
МОДЕЛЬ ПІДГОТОВКИ МАЙБУТНЬОГО ВЧИТЕЛЯ В ПЕДАГОГІЦІ ГЕРБАРТІАНЦІВ
}

Н. О. Федчишин

ДВНЗ “Тернопільський держсавний медичний університет імені І. Я. Горбачевського МОЗ Украйни”

\section{MODEL OF TRAINING OF FUTURE TEACHER IN THE PEDAGOGY OF HERBARTIANS}

\author{
N. O. Fedchyshyn \\ SHEI "Ternopil State Medical University by I. Ya. Horbachevsky of MPH of Ukraine"
}

\begin{abstract}
У статті проаналізовано сутність підготовки майбутнього вчителя в гербартіанській педагогіці; розкрито зміст основних ідей теорії і практики навчання у заснованих гербартіанцями педагогічних семінаріях при університетах; з'ясовано основний акцент гербартіанців - дидактичну підготовку вчителя й головні ознаки добре підготовленого педагога - "педагогічний інтерес”, “педагогічну здатність міркувати» й «педагогічний такт”.
\end{abstract}

The given article focuses on the analysis of the essence of future teacher training in Herbartianism pedagogics. It reveals the key theoretical and practical issues of studying process in pedagogical seminaries adopted by herbartians, that is the didactic teacher training and the main features of a well-trained pedagogist such as "pedagogical interest", "pedagogical ability to think" and "pedagogical tact".

Вступ. Свроінтеграційні тенденції чітко відслідковуємо сьогодні у всіх сферах життєдіяльності. Європейські стандарти якості життя, розвиток освіти і культури, підготовка компетентних спеціалістів нової генерації привертають особливу увагу. У цьому контексті розробка вітчизняної концепції якісної освіти значною мірою орієнтується на освітні здобутки держав Європи, лідерами є країни з традиціями у сфері освітньої діяльності, зокрема підготовки вчителя, до яких, безперечно, належить Німеччина. Професійна підготовка вчителів у Німеччині, які мають грунтовні знання у сфері педагогіки, психології, етики, культурології, володіють змістом, методикою і мовою предмета викладання, інтерактивними методами, є пріоритетним напрямом розвитку освіти. Проте розробка сучасних концепцій освіти значною мірою спирається на національні та світові надбання минулого, які потребують ретельного вивчення та грунтовного дослідження. У цьому руслі наше зацікавлення привертають прогностичні, глибокі та практичні міркування Й.-Ф. Гербарта та його послідовників щодо підготовки майбутніх учителів.

У Німеччині активно розроблялася філософія освіти і підготовка учителя у гербартіанстві займала чільне місце. До вивчення цього питання зверталися Е. Ангальт, О. Байєр, А. Бліднер, М. Вінклер, К. Гай- нце, К. Генкель, П. Зедлєр, Е. Мюллєр, А. Ребле, Т. Рутт та ін. При аналізі підготовки майбутніх учителів у розумінні гербартіанців вчені-педагоги наголошували на популярності їх вчення та впровадженні у практику.

Метою статті $є$ аналіз підготовки майбутніх учителів у поглядах гербартіанців. Для розгляду даного питання слід виконати такі завдання: проаналізувати ідеї Й.-Ф. Гербарта та його учнів щодо підготовки учителя й дослідити результати роботи, заснованих гербартіанцями, педагогічних семінарій при університетах.

Основна частина. Як зазначають дослідники, саме Й.-Ф. Гербарт перший зробив надзвичайно важливу спробу сформувати у вчителя науково-педагогічний світогляд та виробити філософію вчительства. Як зауважив С. Левітін, Й.-Ф. Гербарт був популярний серед учителів середніх навчальних закладів, адже вся тогочасна система освіти середньої школи Німеччини була побудована на його педагогіці [1].

Проблема підготовки вчителя отримала вагомий поштовх від німецького класика педагогіки, який проаналізував означене питання в історичному аспекті й отримав визнання серед вчителів-практиків Німеччини. Саме завдяки Й.-Ф. Гербарту питання "педагогічного такту” стало спільним надбанням педаго-

(c) Н. О. Федчишин 
гічного мислення і діяльності. У праці “Педагогічні записки” (“Padagogische Schriften”) (1802) з'ясовано, що педагогічний такт виробляється у процесі педагогічної практики, власне у впливі на наші відчуття. Відчуття, за Й.-Ф. Гербартом, поєднуються завдяки взаєморозумінню між учнем та учителем через педагогічний вплив [5]. Учений та його послідовники наголошували, що успіхи чи невдачі всіх педагогічних зусиль залежать від того, як учитель “виробляє" свій такт через мислення, обдумування, дослідження, науковість.

У педагогіці В. Райна домінуючою була особистість учня. 3 цієї позиції акценту на учневі він пропонував розглянути питання підготовки учителя. Гербартіанець зосередив увагу на важливості передання знань з “покоління в покоління, від душі до душі, від особистості до особистості” [9]. Саме завдяки душі учителя, передачі його багатого духовного світу у молодого покоління "проросте добірне зерно, укріпиться й помножиться" [там само]. Він таким чином характеризував “особливу” підготовку вчителя: 1) набуті знання слід ретельно перевіряти і впорядковувати; відповідно підібраний матеріал - пов' язати 3 попередньо поданим, що сприятиме цілісності й досконалості; 2) при пошуку психологічних передумов навчального процесу в центрі уваги є учень, на якого спрямована педагогічна діяльність (при цьому можна вирішити науково обгрунтовані психолого-педагогічні завдання); 3) основне для учителя - займатися теорією і практикою, спостерігати, знаходити й опрацьовувати новий матеріал, вправлятися у своїй спеціалізації, вміти робити висновки. Гербартіанець підкреслював, що учителю слід бути митцем, актором й володіти моральними якостями. Зокрема він наголошував, що “не лише науково обгрунтовані знання $є$ у педагогіці найбільш важливими, а "мистецька" праця, іiі безпосередній вплив на серця молодих людей” [11].

Щодо взаємозв'язку теорії і практики, то гербартіанці виходили 3 того, що педагоги-практики через свою необізнаність у наукових поясненнях швидше опираються на власний досвід і спостереження. Вони переконували, що це негативно впливає на педагогічну кар'єру вчителя, оскільки він, учитель, діє на власний розсуд й досвід та не сприймає із-зовні жодних пропозицій і підказок. Послідовники Й.-Ф. Гербарта підтримали свого учителя у тому, що хто вчиться мистецтва у діяльності, мислення - у науці, сам визначає свої подальші дії і вчинки, керовані досвідом [6]. Важливим є, на їхню думку, той факт, що учитель перед плануванням заняття завжди повинен мати перед собою “картину чистої душі”, замість того, щоб навантажити свою пам'ять незначним й другорядним. В. Райн, Т. Ціллєр, Ф.-В. Дьорпфельд та ін. вважали неприпустимим той момент, коли викладачі вишів віддавалися лише науці й не пристосовували свої знання, досягнення науки до потреб і можливостей пересічного учня. Вони вважали, що такої ситуації можна було б уникнути, якби при університетах створювалися педагогічні семінарії й професорсько-викладацький склад нарівні працював із учителями-практиками $[4,11,13]$.

Ф.-В. Дьорпфельд охарактеризував В. Райна як розумного, кмітливого, добросердечного вчителя й досить відомого вже на той час педагога-практика. У 1885 р. В. Райн очолив кафедру педагогіки в Сні та 3 дозволу міністра культури Ваймера заснував народну школу при педагогічній семінарії (три класи для початкового, середнього та вищого рівнів). Його лекції із загальної педагогіки опиралися в першу чергу на дві філософські дисципліни: етику й філософію. Окрім того він увів додаткові лекції: “Життя і вчення Й.-Ф. Гербарта" ("Herbarts Leben und Lehre"), "Проблеми сучасної педагогіки" ("Probleme der modernen Padagogik") та "Шкільна освіта за кордоном" ("Auslandisches Schulwesen”). За ідеєю та під керівництвом В. Райна в 1895 - 1900 pp. було видано спочатку семитомник (перше видання), пізніше десятитомник (друге вид.) “Довідника-енциклопедіїпедагогіки” (“Enzyklopadisches Handbuch der Padagogik") [7].

Педагогіка була для В. Райна, як і медицина, прикладною наукою. Коли друга базувалася на знаннях занатомії й фізіології, то педагогіка опиралася, на його переконання, на етику й психологію. Свої думки він виклав у праці “Теорія та практика" ("Theorie und Praxis”), опубліковану в “Довіднику-енциклопедії педагогіки" (“Enzyklopadisches Handbuch der Padagogik", 1911), де грунтовно пояснив проблематику теорії i практики в педагогіці. Розбіжності між теорією і практикою він побачив у низькій оцінці теорії на противагу практиці. Переоцінку практики він виявив у перебільшенні ролі досвіду [9]. Педагогічна наука була для В. Райна нічим іншим як систематизовано впорядкованим, обгрунтованим уособленням “чистого" досвіду, набутого і випробуваного людством у навчанні й вихованні. Педагог розумів, що практика $є$ початком педагогічної науки і відіграє провідну роль. Він пояснював, що лише тоді спостерігається прогрес, коли практик усвідомлює власні недоліки й починає цікавитися досвідом і результатами інших педагогів. В. Райн стверджував, що можна досягти вищого наукового рівня, коли привести в систему 
беззаперечних понять поєднання результатів думок і вчинків з безперервною практикою. Лише тоді, переконував педагог, теорія передуватиме практиці. Він зазначав, що “здоровий” прогрес відслідковується лише тоді, коли відбувається кругообіг від теорії до практики і навпаки. Хоча теорія вказує лише напрям, проте розвиваються обидві переплітаючись. В. Райн підкреслював, що в такому взаємопроникненні “гола” практика є “сліпим, невпевненим поступом”, в якому відсутня ясність теоретичного пізнання [9].

Наукові погляди Й.-Ф. Гербарта вплинули в основному на педагогічну практику. Безперечним доказом цього є заснована ним у Кьонінгсберзі практична школа для студентів підготовчих курсів (1808), де він не лише читав лекції $з$ педагогіки, але й проводив диспути із запропонованих студентами тем. Зокрема Й.-Ф. Гербарт писав куратору Кьонінгсберзького університету: “якщо працювати щодня впродовж години 3 невеликою кількістю студентів, які ознайомлені 3 моєю педагогікою, то швидко під моїм керівництвом вони будуть здатні передавати грунтовні знання новим учням" [6]. Його пропозиція була підтримана. Пруський король Фрідріх-Вільгельм III вимагав глибоких реформ у системі навчання та виховання. Ф. Ніколовіус та А. Зюферн, перший- особливий поціновувач та інший - колишній студентський товариш Й.-Ф. Гербарта запропонували термінове “обновлення” навчальних закладів (вузів й гімназій) як міських, так і сільських. Вони звернули увагу на подані Й.-Ф. Гербартом з цього приводу міркування в "Ескізі створення педагогічної семінаріï” ("Entwurf zur Anlegung eines padagogischen Seminars") (1809) [5]. У цьому так званому “інституті дидактики” викладачпрактикант працює на заняттях 3 педагогіки з 2-3 студентами 4-5 год на тиждень. Як наголошував Й.-Ф. Гербарт, це була унікальна можливість впроваджувати нові навчальні методи, перевірятиїх на практиці та ознайомлювати із здобутками педагогічного досвіду і звернувувагу, що останній має бути визнаним у наукових колах, завершеним й обгрунтованим [там само].

Як підтвердження вищезазначеного 9 грудня 1842 p., вже після смерті Й.-Ф. Гербарта, його послідовник К.-Ф. Стой відкриває в Єні педагогічні семінарію та інститут, в яких здобувають освіту обидві статі нарівні, чого не було до цього часу. 31848 р. у педагогічній семінарії навчаються діти нижчих верств населення й К.-Ф. Стой докладає зусиль, щоб таких класів стало білыше. Даний навчальний заклад, як практична школа, налічував до 170 учнів й став моделлю для створення педагогічної семінарії при Ляпцігському університеті. Кількість учителів-практиків збільшилася вже в пер- ший рік існування від 4 до 12. На той час зростає i кількість бажаючих навчатися у цій школі-семінарії [11]. Окрім класних керівників тутпрацювализучнямиштатні та позаштатні вчителі-практиканти. Штатні - до початку роботи в семінарії повинні були певний час пройти стажування у семінарській школі. У їхньому розпорядженні були три класи й, відповідно, три класні керівники, які готували учителів-практикантів до навчальних занять, здійснювали письмові зрізи їх підготовки й звітували перед директором. Початківці могли вести заняття з вибраного ними предмета лише після багаторазових відвідин уроків з даної дисципліни.

Як зазначив О. Байєр, обов'язки класного керівника виконували два учителі-практиканти. Навчальний матеріал готували на вимогу директора й викладача-керівника у письмовому вигляді й він підлягав ретельній перевірці [3]. Класні керівники несли відповідальність за навчально-виховну роботу практикантів й мали право відвідати будь-яке заняття практиканта без попередження, робити зауваження, давати вказівки, корисні поради. Навчальний матеріал був чітко розподілений за темами та заняттями й, окрім того, додавалися підготовлені навідні питання i, для порівняння, результати з попередніми групами.

Наприкінці кожного тижня відбувалася конференція практикантів всієї семінарії, на якій обговорювали навчальні заняття, підготовку до наступного тижня (виготовлення таблиць і т. п.), заходи управління та дисципліни. Всі працівники були зобов'язані відвідувати щотижневі збори в семінарії. Після конференції двічі на тиждень упродовж 2 год проводилися теоретично-педагогічні тренінги, результати яких вносилися у книгу “Результати практики”. До щотижневих зборів у семінарії належали: теоретичний аналіз, практикум та конференція. На теоретичний аналіз учителі-практиканти готували реферати 3 питань етики, психології, педагогіки, методики, практикум включав пробні лекції. На конференцію класний керівник визначав на кожного практиканта одного рецензента, котрий за відповідною схемою подавав за день до початку роботи свої висновки. Окрім того практикант здійснював оцінку своєї праці й на основі обох доповідей, відповідей на поставлені під час обговорення питання була підсумована загальна оцінка. На конференцію виносилися такі питання: 1) обговорення практикуму: зачитування самокритичних і критичних зауважень, дискусія, рецензія; 2) аналіз теоретичних робіт; 3) план перехідних уроків; 4) різне.

Після грунтовного пояснення призначення педагогічних семінарій при університетах В. Райн апелював до університетів, щоб не відмовлялися в інтере- 
сах народної освіти всіх прошарків від народного виховання, а залучали й використовували різні можливості в цій сфері. Він закликав організувати й устаткувати виховні заклади для наукової педагогіки з метою їх впливу на гімназії, педагогічні семінарії та інші навчальні заклади й шкільні інституції.

Контролю за навчальним процесом слугували щотижнева перевірка, письмові щотижневі звіти викладачакерівника й учителів-практикантів, вибірковий щотижневий фаховий іспит перед директором [3]. Навчання в семінарській школі грунтувалося на постійній концентрації уваги, на результатах синтезу й системності. Водночас учителі-практиканти були задіяні у шкільних святах, виїздах на природу, походах, поїздках. Ляпцігська педагогічна семінарія булазакрита в 1882 р. після смерті Т. Ціллєра, проте і надалі продовжувала готувати педагогічні кадри семінарія в Сні.

В. Райн у праці “Педагогіка в системному викладі" ("Padagogik in systematischer Darlegung") окреслив значення грунтовної підготовки вчителя, оскільки саме вона визначає подальше виховання громадянина, його моральних якостей, що було для нього основним елементом призначення народної освіти. Гербартіанець виступив проти упередженої думки представників вищих навчальних закладів, що вчитель повинен бути, в першу чергу, вченим, і лише після цього педагогом. Він наголосив на діаметрально протилежній думціважливості симбіозу гарного науковця й “тямущого" вчителя [10]. Власне, першочергове завдання педагогічної семінарії університету В. Райн убачав у подалышому розвитку педагогічної науки та в теоретичній і практичній підготовці вчителя-вихователя. Таке подвійне завдання, на його думку, не в силі вирішити ні держава, ані інша приватна інституція, а лише - університет, де практична філософія по-новому акцентує на питаннях змісту й мети людського життя, де емпірична психологія намагається розкрити закони духовного та душевного життя, а психологія здійснює розвідки й виявляє нові шляхи фізичного здоров’я. Послідовник Й.-Ф. Гербарта стверджував, що університет водночас має можливість уводити в науку нові педагогічні генерації, щоб вони, по-перше, отримали бачення завдань виховання, по-друге, краще могли розуміти проблеми молодого покоління та, по-третє, активно працювали задля національного виховання. Ці три умови гербартіанець відмітив у діяльності педагогічної семінарії при університеті Єни.

Завдання педагогічної семінарії при університеті гербартіанець вбачав у подальшому розвитку педагогічної науки, в теоретичній і практичній освіті наполегливих учителів-вихователів. Обидва завдання, на його переконання, були взаємопов' язані. Як державна освіта, так і приватні школи докладали зусилля до виховання молодої генерації. Тому для нього не виникало питання, чи спираються вони при цьому на університетську освіту, де панувала практична філософія, а емпірична психологія намагалася розкрити закони душі індивідуума. У цьому В. Райн побачив можливість підготувати підростаюче покоління учителів-вихователів до наукової роботи й закласти основи практичної діяльності. Він тим самим акцентував увагу на тому, що педагогічна семінарія при університеті Сни виконує ці завдання.

В. Райн пройшов навчання в семінарії у К.-Ф. Стоя та Т. Ціллєра й самостійно намагався пізніше як штатний професор педагогіки в Сні вирішити проблему підготовки вчителів у Німеччині. Він наголошував на мистецькому та різнохарактерному компоненті педагогічної професії й вимагав загальної фахово-наукової, естетично зорієнтованої підготовки учителявихователя. Користь від такої підготовки для науки і суспільства, на яку були націлені гербартіанці, історики педагогіки не піддавали сумніву.

Запропоновані Й.-Ф. Гербартом педагогічні процеси мислення і діяльності К.-Ф. Стой та Т. Ціллєр прискорили таким чином, що на початку їхньої академічної діяльності були запропоновані й організовані нимипедагогічні семінарії у формі навчальних закладів, в яких була можливість підготувати молодих учителів-практикантів до майбутньої навчально-виховної роботи.

Педагогіка гербартіанців (від Й.-Ф. Гербарта до Т. Ціллєра та В. Райна) отримала чітке й ретельне напрацювання і стала доступною та популярною серед німецьких учителів. Послідовники Й.-Ф. Гербарта дійшли висновку, що вона є сумою прийомів, положень, вмінь і вказівок для досягнення поставленої мети i, окрім того, завжди перебуває у діяльності. Гербартіанці суголосно зі своїм учителем переконували, що лише у діяльності можна навчитися мистецтва й підготувати справжнього фахівця $[9,11,12$, 13]. Особливу увагу на дидактичну підготовку вчителів звернув Т. Ціллєр. Він, зокрема, наголошував на важливості досягнення педагогічної майстерності за посередництвом “педагогічного такту”. Гербартіанець зазначав, що досягти його можна лише шляхом власної практики, у діяльності, проте спираючись на вказівки і методи теорії. Останні повинні бути напрацьовані ще до практичної діяльності [13].

Висновки. Гербартіанська педагогіка, однією з рис якої було забезпечення тісного взаємозв' язку та взаємообумовленості теорії і практики навчання, отримала свою чітку й детальну розробку й стала доступною 
широким верствам німецьких педагогів. Гербартіанці зробили основний акцент на дидактичній підготовці вчителів й з цієї позиції вказали на головні ознаки освіченого, добре підготовленого педагога - "педагогічний інтерес", “педагогічну здатність міркувати” й “педагогічний такт”. За допомогою дидактичних наукових робіт, взаємодії теорії і практики, спілкування учителя та учня можна досягти педагогічного мистецтва.

Вчитель, на переконання послідовників Й.-Ф. Гер-

\section{Лiтература}

1. Левитин С. А. Педагогические идеи Гербарта и Монтессори. Т. I / С. А. Левитин. - М. : Лит.-изд. Отдел нар. комта по просвещ., 1918. - 102 с.

2. Anhalt E. In welche Zukunft schaut die Padagogik? Herbarts Systemgedanke heute / Elmar Anhalt. - 1. Auflage, Verlag IKS Garamond, 2009. - 177 S.

3. Beyer O. W. Ziller, Tuiskon. In: Encyklopadisches Handbuch der Padagogik / Herausgegeben von W. Rein, Jena, zweite Auflage, 10. Band, Langensalza, 1910.-S. 508.

4. Dorpfeld F. W. Gesammelte Schriften. Zweiter Band: Zur allgemeinen Didaktik / Friedrich Wilhelm Dorpfeld. - Erster Teil. Grundlinien einer Theorie des Lehrplans. Nebst dem Erganzungsaufsatz: Die unterrichtliche Verbindung der sachunterrichtlichen Facher. Gutersloh, 1894. - 131 S.

5. Herbart J. F. Padagogische Schriften/hg. Von W. Asmus, 3 Bde. - Stuttgart, 1982. - $257 \mathrm{~S}$.

6. Herbart J. F. Umri $\beta$ padagogischer Vorlesungen Beigef. Werk Rede bei Eroffnung der Vorlesungen uber Padagogik [u.a.] / Johann Friedrich Herbart. Besorgt von Josef Esterhues Ort Paderborn Verlag Schoningh, 1964.-248 S.

7. Rein W. (HG.) Encyklopadisches Handbuch der Padagogik /WilhelmRein.-Band 1-7. [7 Bd.].-Beyer \& Sohne, Langensalza, 1895. - 6000 S. - 2. Aufl. Langensalza, 1903-11.-10 Bande.Band 8. -937 S.; Band 9.-911 S.; Band 10.-1026 S.

8. Rein W. Herbart und die Herbartianer. Ein Beitrag zur Geschichte der Philosophie und der Padagogik. Sonderabdruck барта, повинен володіти ентузіазмом й чуттям, авторитетом і тактом, любов'ю до учня й глибокими знаннями. До його обов'язків також належить готовність до прогнозування поведінки в будь-яких ситуаціях ї̈х правильна оцінка, побудова чіткого плану як навчання, так і виховання, вміння бути художником, внутрішньо переживати, бачити, відчувати, розуміти і вчити інших, викликаючи при цьому в учнів інтерес.

aus dem encyklopadischen Handbuch der Padagogik von W. Rein in Jena, zusammengestellt aus den Arbeiten von Thilo, Flugel, Rein, Rude / Wilhelm Rein. - Beyer \& Sohne, Langensalza, 1897.-154 S.

9. Rein W. Padagogik in systematischer Darstellung/Wilhelm Rein. - Band 1: Grundlegung. Band 2: Die Ausfuhrung. [2 Bd.]. 2-3. Aufl. - Beyer \& Sohne, Langensalza, 1911.-348 S.

10. Rein W. Padagogik in systematischer Darstellung / Wilhelm Rein. - 3. Bd. C.: Methodologie. Die Lehre von den Mitteln der Erziehung. 2. Aufl. - Beyer \& Sohne, Langensalza, 1912. $-361 \mathrm{~S}$.

11. Rein W. Theorie und Praxis des Volksschulunterrichts nach Herbartschen Grundsatzen. Ein theoretisch-praktischer Lehrgang fur Lehrer und Lehrerinnen sowie zum Gebrauch in Seminaren/Wilhelm Rein, Pickel, Eduard Scheller. - 4 Bde. [4 Bde in einem Buch]. 2. Aufl. - Bleyl \& Kaemmerer, Dresden, 1881.-732 S.

12. Stoy K. V. Schulordnung fur die Seminarschule zu Jena / Karl Volkmar Stoy. - Druck von A. Neuenhahn, Jena, 1881.$70 \mathrm{~S}$.

13. Ziller T. Einleitung in die allgemeine Padagogik / Tuiskon Ziller. - Verfasserang von Tuiskon Ziller, Vorlesunden uber Allgemeine Padagogik. - Leipzig, Verlag Teubner 1856 Umfang VIII, $182 \mathrm{~S}$.

14. Ziller T. Materialien zur speziellen Padagogik / Tuiskon Ziller.-Dresden: Bley\&Dammerer. 1886.-296 S. 